\title{
Effect of Integrated Nitrogen Management on Yield and Economics of Foxtail Millet Genotypes
}

\author{
B. Selectstar Marwein, Rajesh Singh* and Punnam Chhetri
}

Naini Agricultural Institute, SHUATS, Prayagraj-211007, India

*Corresponding author:

\begin{abstract}
A B S T R A C T
Keywords

Foxtail millet, Integrated nitrogen management, Yield and Economics

Article Info

Accepted:

22 July 2019

Available Online:

10 August 2019

A field experiment was conducted during the kharif season of 2018 on Foxtail millet of varieties SIA 3156 and SIA 326 (PRASAD) at Crop Research Farm, Department of Agronomy, Naini Agricultural Institute, SHUATS, Prayagraj (U.P). the experiment was laid out in Randomized Block Design with 6 treatments combinations, consisting of two varieties of Foxtail millet (SIA 3156, SIA 326) and nitrogen management viz., Farmer's practice $(\mathrm{NPK}=40: 20: 0), 100 \%$ RDF $(\mathrm{NPK}=50: 30: 20)), 75 \% \mathrm{RD} \mathrm{N}+25 \% \mathrm{~N}$ through PM, 75\% RD N + 25\% N through PM + Azospirillum SI, 50\% RD N + 50\% N through $\mathrm{PM}$ and $50 \% \mathrm{RD} \mathrm{N}+50 \% \mathrm{~N}$ through PM + Azospirillum SI. The Experiment revealed that in variety SIA 3156, integration of inorganic fertilizer of $75 \%$ RD N through Urea + $25 \% \mathrm{~N}$ through PM + Azospirillum Seed Inoculation resulted in maximum grain yield (2.31 t /ha), higher Net return ( $₹ 32,229.35 /$ ha) and maximum B:C ratio (2.59). In variety SIA 326, the experiment reveals that $75 \%$ RD N through Urea+ $25 \% \mathrm{~N}$ through Poultry Manure found out to be the best treatment which result in highest grain yield $(2.31 \mathrm{t} / \mathrm{ha})$, highest Net return (₹ 25,946.09/ha) and B:C ratio (2.28).
\end{abstract}

\section{Introduction}

Foxtail millet (Setaria italica L. Beauv) is important minor millet belonging to the family Poaceae. In India, the cultivation of foxtail millet is confined to Andhra Pradesh, Karnataka, and Tamil Nadu. It's grain used for human consumption and a feed for poultry and cage birds. It is used in several food preparations like chapati, fermented bread, biscuits, malts, etc. the stalks are used as fodder and for thatching. It is rich in micronutrients and good for diabetic patients. It protects against cancer and related heart diseases (Anon., 1993). Foxtail millet comes under drought tolerant crop and it can be grown as a short-term catch crop. It is adapted to a wide range of elevation, soils, and temperatures. It is usually grown in the marginal lands having low level of nutrients and organic matter. However, it responses to the amount of fertilizers used and they significantly contribute in yield and yield attributing characters. Fertilizer management is one of the important cost-effective factors known to augment the crop production. The supplementation of fertilizers along with the organic manure plays the key role in overall 
balance supply of nutrients owing to the better growth and production of the crop. The potential of foxtail millet as rainfed crop has not been fully exploited.

\section{Materials and Methods}

The experiment was carried out during Kharif season 2018 at Crop Research Farm, Department of Agronomy, Naini Agricultural Institute, Sam Higginbottom Institute of Agriculture, Technology and Sciences, Prayagraj (U.P.), which is located at $25^{\circ} 40^{\prime} 94$ $\mathrm{N}$ latitude and $81^{\circ} 85^{\prime} 35^{\prime \prime}$ E longitude of 98 meter above the sea level (MSL). This area is situated on the right side of the river Yamuna by the side of Allahabad Rewa Road about 5 $\mathrm{km}$ away from Allahabad city. The soil of experimental field was sandy loam, $\mathrm{pH}$ of soil was 7.3 with $0.690 \%$ organic $\mathrm{C}$, having available $\mathrm{N}, \mathrm{P}, \mathrm{K}, 278.75,18.2$ and $250.5 \mathrm{~kg}$ $\mathrm{h}^{-1}$ respectively. The experiment involving two varieties of Foxtail millet SIA 3156 and SIA 326 (Prasad) which was laid out in randomized block design with six treatments replicated thrice, comprising Farmer's practice $(\mathrm{NPK}=40: 20: 0), 100 \% \mathrm{RDF}(\mathrm{NPK}=$ 50:30:20)), $75 \%$ RD N + 25\% N through PM, $75 \% \mathrm{RD} \mathrm{N}+25 \% \mathrm{~N}$ through $\mathrm{PM}+$ Azospirillum SI, 50\% RD N + 50\% N through $\mathrm{PM}$ and $50 \% \mathrm{RD} \mathrm{N}+50 \% \mathrm{~N}$ through $\mathrm{PM}+$ Azospirillum SI.

\section{Results and Discussion}

\section{Effect on yield of foxtail millet}

The data on yield as influenced by Integrated Nitrogen Management on two varieties of Foxtail millet are presented in Table 1. In variety SIA 3156 , the treatment $\mathrm{A}_{14}(75 \%$ RDN through urea $+25 \% \mathrm{~N}$ through Poultry Manure + Azospirillum SI) was recorded with highest grain yield (2.31 t /ha). However, $A_{16}$ (50\% RD $\mathrm{N}$ through urea $+50 \% \mathrm{~N}$ through Poultry Manure + Azospirillum SI) and treatment $\mathrm{A}_{13}$ (75\% RD N through urea $+25 \%$ $\mathrm{N}$ through Poultry Manure) were statistically at par with treatment $\mathrm{A}_{14}(75 \% \mathrm{RD} \mathrm{N}$ through urea $+25 \% \mathrm{~N}$ through Poultry Manure + Azospirillum SI). With regard to straw yield and harvest index, there was no significant. However treatment $\mathrm{A}_{12}$ (RDF $(\mathrm{NPK}=$ 50:30:20) was recorded with maximum straw yield (3.87 t/ha). Integration of inorganics, organics and bio-fertilizer might have exerted a pronounced effect on yield of Foxtail millet. Poultry manure has also significant effect on grain yield of foxtail millet as reported by Damar et al., 2016. In respect of Azospirillum inoculated treatments, a well-developed root system coupled with increased availability of nutrients could have promoted greater uptake of nutrients resulting in higher grain yield (Rana, 1985).

In variety SIA 326, a significant grain yield $(1.78 \mathrm{t} / \mathrm{ha})$ was recorded with treatment $\mathrm{A}_{23}$ (75\% RD N through urea $+25 \% \mathrm{~N}$ through Poultry Manure). There were no significant with regard to straw yield. However, treatment $\mathrm{A}_{23}$ (75\% RD N through urea $+25 \%$ $\mathrm{N}$ through Poultry Manure) was recorded with maximum straw yield (5.33 t/ha). The conjunctive use of organic and inorganic sources has beneficial effect on physiological process of plant metabolism and growth thereby leading to higher grain yield and straw. The easy availability of nitrogen due to mineralization of organics influences the shoot and root growth favouring absorption of other nutrients. Similar results were obtained by Varalakshmi et al., (2005), Yakadri and Reddy (2009), Umesh et al., (2006) and Basavaraju and Purushotham (2009).

\section{Effect on economics of Foxtail millet}

In variety SIA 3156 , treatment $\mathrm{A}_{14}(75 \% \mathrm{RD}$ $\mathrm{N}$ through urea $+25 \% \mathrm{~N}$ through Poultry Manure + Azospirillum SI) was recorded with highest Gross return (₹ 52,526.66 /ha), Net 
return (₹ 32,229.35/ha) and B:C ratio (2.59). While treatment $\mathrm{A}_{11}$ [Farmer's practice $(\mathrm{NPK}=40: 20: 0)]$ was recorded with lowest Gross return (₹ 41,733.26/ha) and treatment
$\mathrm{A}_{16}(50 \% \mathrm{RD} \mathrm{N}$ through urea $+50 \% \mathrm{~N}$ through Poultry Manure + Azospirillum SI) was recorded with lowest Net return (₹ 22,777.89/ha) and B:C ratio (2.01).

Table.1 Effect of Integrated Nitrogen Management on yield of Foxtail millet

\begin{tabular}{|c|c|c|c|c|}
\hline \multirow{3}{*}{ Fertilizer Treatment } & \multicolumn{4}{|c|}{ Varieties } \\
\hline & \multicolumn{2}{|c|}{ SIA 3156} & \multicolumn{2}{|c|}{ SIA 326 (PRASAD) } \\
\hline & $\begin{array}{c}\text { Grain Yield } \\
(\mathrm{t} / \mathrm{ha})\end{array}$ & $\begin{array}{c}\text { Straw Yield } \\
(\mathrm{t} / \mathrm{ha})\end{array}$ & $\begin{array}{c}\text { Grain Yield } \\
(\mathrm{t} / \mathrm{ha})\end{array}$ & $\begin{array}{c}\text { Straw Yield } \\
(\mathrm{t} / \mathrm{ha})\end{array}$ \\
\hline Farmer's practice $(\mathrm{NPK}=40: 20: 0)$ & 1.73 & 3.53 & 1.28 & 4.74 \\
\hline RDF (NPK= 50:30:20) & 1.81 & 3.87 & 1.46 & 4.12 \\
\hline $75 \%$ RD N + 25\% N through PM & 2.09 & 3.27 & 1.78 & 5.33 \\
\hline $75 \%$ RD N + 25\% N through PM + Azospirillum SI & 2.31 & 3.16 & 1.37 & 5.20 \\
\hline $50 \%$ RD N + 50\% N through PM & 1.95 & 3.13 & 1.23 & 4.08 \\
\hline $50 \%$ RD N + 50\% N through PM + Azospirillum SI & 2.15 & 3.59 & 1.37 & 4.30 \\
\hline S.E.(m) \pm & 0.10 & 0.62 & 0.09 & 0.82 \\
\hline $\mathrm{CD}(\mathbf{P}=\mathbf{0 . 0 5})$ & 0.31 & - & 0.30 & - \\
\hline
\end{tabular}

Table.2 Effect of Integrated Nitrogen Management on Economics of Foxtail millet

\begin{tabular}{|c|c|c|c|c|c|c|}
\hline \multirow{3}{*}{ Fertilizer Treatment } & \multicolumn{6}{|c|}{ Varieties } \\
\hline & \multicolumn{3}{|c|}{ SIA 3156} & \multicolumn{3}{|c|}{ SIA 326 (PRASAD) } \\
\hline & $\begin{array}{l}\text { Gross } \\
\text { return } \\
\text { (₹ /ha) }\end{array}$ & $\begin{array}{c}\text { Net } \\
\text { return } \\
\text { (₹ /ha) }\end{array}$ & $\begin{array}{l}\mathrm{B}: \mathrm{C} \\
\text { ratio }\end{array}$ & $\begin{array}{l}\text { Gross } \\
\text { return } \\
(₹ / / h a)\end{array}$ & $\begin{array}{c}\text { Net } \\
\text { return } \\
\text { (₹ /ha) }\end{array}$ & $\begin{array}{l}\mathrm{B}: \mathrm{C} \\
\text { ratio }\end{array}$ \\
\hline Farmer's practice $(\mathrm{NPK}=40: 20: 0)$ & $41,733.26$ & $24,556.76$ & 2.42 & $33,873.34$ & $16,696.84$ & 1.97 \\
\hline RDF (NPK= 50:30:20) & $43,866.74$ & $25,847.84$ & 2.43 & $35,699.94$ & $17,681.04$ & 1.98 \\
\hline $75 \%$ RD N + 25\% N through PM & $48,333.34$ & $28,086.03$ & 2.39 & $46,193.40$ & $25,946.09$ & 2.28 \\
\hline $\begin{array}{l}75 \% \text { RD N + 25\% N through PM + } \\
\text { Azospirillum SI }\end{array}$ & $52,526.66$ & $32,229.35$ & 2.59 & $39,673.26$ & $19,375.95$ & 1.95 \\
\hline $50 \%$ RD N + 50\% N through PM & $45,253.34$ & $22,777.89$ & 2.01 & $32,700.06$ & $10,224.61$ & 1.42 \\
\hline $\begin{array}{l}50 \% \text { RD N + 50\% N through PM + } \\
\text { Azospirillum SI }\end{array}$ & $48,773.34$ & $26,247.89$ & 2.16 & $36,006.66$ & $13,481.21$ & 1.60 \\
\hline
\end{tabular}

In variety SIA 326 , Treatment $\mathrm{A}_{23}(75 \% \mathrm{RD}$ $\mathrm{N}$ through urea $+25 \% \mathrm{~N}$ through Poultry Manure) was recorded with highest Gross return (₹ 46,193.40 /ha), Net return (₹ 25,946.09/ha) and B:C ratio (2.28). While treatment $\mathrm{A}_{25}(50 \% \mathrm{RD} \mathrm{N}$ through urea $+50 \%$ $\mathrm{N}$ through Poultry Manure) treatment was recorded with lowest Gross return (₹ $32,700.06 / \mathrm{ha}$ ), Net return (₹ 10,224.61 /ha) and B:C ratio (1.42). Ramdev et al., (2017) reported that integration of Poultry manure with RDF result in higher net return in Pearl millet which is close conformity as reported by Singh et al., (2013) under two years studies on pearl millet.

In variety SIA 3156 , on the basis of the above finding it can be concluded for obtaining 
higher grain yield $(2.31 \mathrm{t} / \mathrm{ha})$, higher Net return (₹ 32,229.35/ha) and maximum B:C ratio (2.59), treatment $\mathrm{A}_{14}(75 \% \mathrm{RD} \mathrm{N}+25 \%$ $\mathrm{N}$ through Poultry Manure + Azospirillum SI) was found to be the best treatment from all other treatments. And in variety SIA 326, it can be concluded for obtaining higher grain yield (2.31 t $/$ ha), higher Net return (₹ 25,946.09/ha) and $\mathrm{B}: \mathrm{C}$ ratio (2.28), treatment $\mathrm{A}_{23}(75 \% \mathrm{RD} \mathrm{N}+25 \% \mathrm{~N}$ through Poultry Manure) was found to be the best treatment from all other treatments.

\section{References}

Bhuva, H. M., and Sharma, S. (2015). Influence of nutrient uptake by irrigation, nitrogen and phosphorus and their effect on quality parameter of rabi pearl millet. Journal of Progressive Agriculture, 6(1), 134-137

Damar, W.K.,Garba, A., Russom, Z., Ibrahim, S. A., Haggai, P.T. and Dikwahal, H.D. 2016. Effect of Poultry Manure on Growth and Yield of Finger Millet (Eleusine Coracana L. Gaertn) In The Northern Guinea Savannah, Nigeria. PAT June,; 12 (1): 173-18.

Devegowda G. 1997. Poultry manure excreta and other wastes as a source organic manures. In: training course on organic farming, UAS, Gkvk, Bangalore, 7-11.

Gruhn, P., Goletti, F. and Yudelman, M. 2000. Integrated nutrient management, soil fertility and sustainable agriculture: current issues and future challenges. IFRPI 2020 Vision Brief.

Intodia.S.K. 1994. Response of foxtail millet(Setaria italica) genotypes to levels of nitrogen and phosphorus under rainfed condition. Indian Journal of Agricultural Sciences 64(12): 861-862.

Liu Y, Ding YF, Wang QS, Meng DX, Wang SH. 2011. Effects of nitrogen and 6benzylaminopurine on rice tiller bud growth and changes in endogenous hormones and nitrogen. Crop Science 51:786-792.

Naik, B., Linge Gowda, T.B.K., Thimme Gowda, S and Sridhara, S. 1995. Effect of integrated nutrient management on growth and grain yield of foxtail millet (Setaria italica L. Beauv.) under rainfed conditions on Alfisols of sub tropical India. Fertilizer News. 40(3): 55-57.

Naik, T.B., Murthy, R.K and Pushpa, K. 2010. Effect of integrated nutrient management on growth and yield parameters of foxtail millet (Setaria italica) under rainfed condition of alfisols. Environment and Ecology. 28(2): 762-765.

Pallavi, Ch., Joseph, B., Aarif Khan,M.A. and Hemalatha,S. 2016. Effect of integrated nutrient management on nutrient uptake, soil available nutrients and productivity of rainfed fingermillet. International Journal of Science, Environment and Technology. 5(5):2798-2813

Rana BS. Efficent management of dry land crops. CRIDA, Hyderabad. 1985; pp. 43.

Shashidhara, G.B and Basavarajappa, R. 1997. Response of little millet genotypes to different doses of NPK fertilizers. Karnataka Journal of Agricultural Sciences. 11(2): 344-346.

\section{How to cite this article:}

Selectstar Marwein, B., Rajesh Singh and Punnam Chhetri. 2019. Effect of Integrated Nitrogen Management on Yield and Economics of Foxtail Millet Genotypes. Int.J.Curr.Microbiol.App.Sci. 8(08): 2543-2546. doi: https://doi.org/10.20546/ijcmas.2019.808.295 